\title{
The Determinant Factors That Effect Teacher Performance of Public Senior High School in Deli Serdang District.
}

\author{
Dra. Miska Gewasari, M.M, Prof. DR. Belferik Manullang, \\ Prof. Dr. Abdul Muin Sibuea M.Pd \\ The State University of Medan
}

\begin{abstract}
The aims of this Research are to reveal determinant factors that affect Teacher Competence. This research measured the direct effect and indirect effect of exogenous variables to endogenous variables. The number of samples is 284 of Public Senior High School teachers taken from 1089 teachers as population. The data were gathered by using a set of questionnaires that had been checked for its validity and reliability. The data then were analyzed by using path analysis model. The results revealed that Teacher Competence, Principal Pedagogical Leadership, School Spiritual Organizational Culture, Job Satisfaction of Teacher Development, and Achievement Motivation effect significantly either directly or indirectly toward Teacher Performance of Public Senior High School in Deli Serdang District.
\end{abstract}

Keywords: Determinant factors, Teacher Competence, Public Senior High School.

\section{Background of the Study}

A good education process start from preparation of superior human resources. Formal education is carried out in the education unit will be the center point of the process of education and become a benchmark in the management of education as a whole, hence the school as an educational organization to be able to optimize the overall performance of existing resources as well as the components of the organization in order to achieve the objective of educational process at school. From the set of resources that the key to the success of the educational process at school, while teachers are the most influential resource in achieving the goals of education in schools. Teacher performance in the execution of their duties as educators and teachers will show how the planned objectives will be achieved. Teacher performance will show how teachers carry out their professional responsibilities as educators.

Gage and Baliner in Sagala explains that teachers have a professional responsibility as educators to change the behavior of learners towards certain maturity. The process of changing the behavior of learners is done with a series of activities in educating and teaching activities are carried out in the education ecosystem in the school where the teacher is a component that has a decisive role.In view of the national education system in Indonesia is seen as positions teacher profession mention teachers are professional educators with the primary task of educating, teaching, guiding, directing, train, assess and evaluate students. This view gives meaning teachers must be demonstrated productivity through maximum performance that will be measured by the achievement of graduates' standards competency. So that the performance of teachers be an essential part of getting attention, both for the principal as the manager, government funders and foundations, as well as user education services.. Understanding of the performance through a management perspective as well as looking at the performance of teachers in education management. In education management, according to the theoretical approach of organizational behavior, school as an organization would be an effective school if the teacher can show the maximum performance. The performance of teachers is seen as the success of teachers in implementing the tasks and responsibilities including the ability to achieve the goals and standards stated. (Danim, Sudarwan. 2008: 83)Teachers as a determining factor in the organization of the school, became an important part that must be managed in a serious and sustained, due to improper management of the teachers will have an impact on the quality of educational output, ie. Students' achievement and overall school performance. At a presentation of the study carried Supriya Heyneman \& Loxley in 1983 in 29 countries found that among the various inputs (input) that determines the quality of education shown by student achievement, one third is determined by the teacher. The study showed in 16 developing countries, teachers contribute to the learning achievement of $34 \%$, while $22 \%$ management, $18 \%$ of study time and physical infrastructure $26 \%$. In the 13 industrialized countries, the contribution of teachers was 36\%,23\% management, $22 \%$ of study time and physical infrastructure $19 \%$. These data indicate a necessity to put the performance of teachers as key to the school management.

Several other studies show how the condition of the quality of education and quality teachers today, and to see the performance of teachers. Results of research conducted by Sudjana showed that $76.6 \%$ of student learning outcomes are influenced by the performance of teachers, with details: the ability of teachers to teach 
contributed $32.43 \%$, mastery of the subject matter contributed $32.38 \%$ and the attitude of teachers to subjects contribute $8.60 \%$. The results of these studies indicate that the performance of teachers into the factors that determine the quality of education. While Fasli Djalal argued that the competence and skills of teachers remains low. This is in line with the opinion Kustono Djoko said that the quality of teachers in Indonesia is still relatively low. Nearly half of the approximately 2.6 million teachers in Indonesia is not suitable as a teacher in schools. While the input of teachers in Indonesia is very weak. Data Research and Education Ministry show attendees test prospective teachers after tests conducted field of study turns out the average score of the test selection is very low. Of 6164 Biology teacher candidates when tested biological average score was only 44.96; of 396 Chemistry teachers tested the average score achieved 43.55. From 7558 English teacher candidates average test results achieved only 37.57. (Sudjana, N. 2009:112; Data Balitbang Depdiknas: http://www.artikelartikel.com/2010/07/06; Unimed.2011).

Theories of organizational behavior at this time developed many experts and have shown how individual performance will affect the effectiveness of the organization, and the factors that cause an individual effectiveness in the organization. The organization will run efficiently and will continue to live, if it can strike a balance between the achievements of organizational goals with individual needs. Elton Mayo through Howtorn trial, has shown that the classical approach cannot achieve production efficiency and labor harmony. For that leaders work to resolve organizational management with a view of the patterns of behavior of workers, especially human relations. (Robbins, Stephen P. 2008:3).

To determine the factors that affect performance, Mc. Shane and Glinow develop a model of organizational behavior. The model they developed known as the Model of Individual Behavior and Results. This model shows the four factors that affect the performance of the individual that is the motivation, capabilities, roles, perceptions and situational factors. According to Shane and Glinow if four of these factors weaken the individual performance will be reduced. Motivation, capabilities, roles, perception and factor this situation is determined by the individual character of value. (McShane, Steven L., and Glinow, Mary Ann Von.

2007:24).In the development of organizational behavior theory, several other theories put forward, such as presented by Colquitt who developed the Integrative models of organizational behavior. The model explains that job performance is determined by (1) the mechanism of the individual in the form of job satisfaction, stress, motivation, trust, fairness and ethics learning and decision making, (2) the individual characters in the form of personality, or the personality and cultural values as well as the ability, (3) mechanism in the form of group leadership, behavior style of leadership: the power of influence, group process, and character group, and (4) the organizational mechanism in the form of organizational culture and organizational structure. (Colquitt.

2009:65). In Phase II Organizational Behavior models developed by Robbins, explained that individual performance can be seen on productivity, absenteeism, employee turnover, citizenship, satisfaction. According to the performance of individuals affected by the behaviors at the level of (1) the individual in the form of characteristic biographical, personality and emotions, values and attitudes, abilities, perception, motivation, individual learning and decision making, (2) group in the form of change and stress, communication, conflict, power and politics, the work team, group structure, leadership and trust and group decision making, and (3) the organizational system in the form of organizational culture, work design and technology, and policies and human resources practices. All factors at each level of this analysis interact with each other and give effect to the performance of individuals. (Robbins, Stephen P. 2003:34; Slocum, John. W \& Hellriegel, Don. 2009:24).

Performance in the opinion of Mc. Clelland (1976:298) has several characteristics, among others; responsible for solving problems, setting goals, feedback and reliable. According to Robbins's; Hersey, P., \& Blanchard, K. (1993:315) performance is a function of the interaction between the ability, motivation, opportunity, Situation, and satisfaction. (McShane, Steven L and Mary Ann Von Glinow 2007:375).

Explanation of the variables related to the teachers' performance described above can be seen from: (1) work satisfaction, (2) achievement motivation, (3) the competence of teachers, (4) the principal's leadership, (5) the school environment to establish a school culture. This research aimed to reveal the direct and indirect effect of exogenous variables to endogenous variables of teachers' performance.

\section{Teacher Competence}

\section{Literature Study}

Competency as the state or quality of being properly or well qualified. Competence in this definition means that the quality should be, or terms or good standard of a job. Competence according to Klemp in Lucia (1999:72) is an underlying characteristic of a person which results in effective and / or superior performance on the job, competence is the nature of an influential person in the performance of their effective and very prominent. According Mulyasa (2005:93), teacher competence is the combination of personal ability, scientific, 
technological, social, and spiritual overall standard of competence set up a teaching profession that includes mastery of materials, understanding of learners, learning educational, personal and professional development.

Professional teachers are teachers who have the competencies required to perform the task of education and teaching. Competence here include knowledge, attitudes, and professional skills, both personal, social, and academic. In other words, the definition of a professional teacher is a person who has the ability and expertise in the field of teacher training so that he/she is able to perform its duties and functions as a teacher with a maximum capability. Professional teachers are educated and trained, and has a rich experience in the field. (Kunandar; 2007:47)

A professional job requiring special requirements, namely (1) requires the skills based on the concepts and theories of science are profound; (2) emphasis on a particular field of expertise in accordance with the profession; (3) requires an adequate level of education: (4) their sensitivity to the social impact of the implementation of the work; (5) allows the development in line with the dynamics of life. In addition to the above requirements, the professional requirements also in the form of (1) has a code of ethics, as a reference in carrying out its duties and functions (2) has a client / service objects that remain, such as a doctor with a patient, a teacher with a student; (3) recognized by the community because it is needed services in the community. (Usman, Moh. Uzer; 2003:36; Ali, Muhammad; 1987:12; Surya, 2005:4).

\section{Principal Pedagogical Leadership}

Leadership is the ability to influence a group toward achievements. There are several definitions of leadership suggested by experts. Stephen P. Robbins. (2008:432) said the leadership of which is the behavior of individuals who direct the activities of the group to achieve common goals. While Katz, Daniel \& Robert L. Kahn (1978:192) said that leadership is the additional influence that exceeds and is above the mechanical needs in directing the organization on a regular basis. Yukl (2001:7) said that leadership is the process of influencing others to understand and agree about what needs to be done and how it can be done effectively, and the process of facilitating individual and collective efforts to accomplish the shared objective.

Several studies on leadership has produced theories about leadership. Kartini Kartono (2008:71) summarized from Terry some leadership theories as follows: (1) theory of autocratic, (2) a psychological theory, (3) sociological theory, (4) theory of supportive, (5) the theory of Laissez Faire, (6) Theory of Behavior Personal, (7) Traits of Great Men, (8) situation Theory, and (9) Theory of humanistic / populist.

When linked with the principal as a leader in his/her school, the functions of the head of the school there are seven kinds are known by the term "emaslim" namely: (1) the principal as an educator, (2) the principal as a manager, (3) the principal as administrator, (4) the principal supervisor, (5) the principal as leader (leader), (6) the principal as an innovator, and (7) of the principal as a motivator. (Ahmad, S, 2001:41).

The school principal quality is principals who have basic skills, personal qualifications, as well as the knowledge and professional skills. According to Tracey (1974:55), basic skills or abilities is a group's ability to be possessed by any leader level, which includes: conceptual skills, human skills and technical skills.

\section{School Spiritual Organizational Culture}

School Spiritual Organizational Culture is a school culture that recognizes that people have an inner life that nurtures and nourished by meaningful work that exist in a community context. Schools with spiritual culture recognizes that people who have the mind and the spirit, trying to find meaning and purpose in their work, and wish to connect with other human beings and want to be part of the school community.

According to Sutrisno (2010:2) organizational culture is defined as a system device values (values), beliefs (beliefs), assumptions (Assumptions), or norms that have long been in force, agreed upon and followed by the members of an organization as a code of conduct and solving the problems of the organization. In the culture of the organization occurred socialization and internalize the values within the members. There are five groups of approaches to the study of culture, namely: (a). an evolutionary approach; (b) particularism approaches; (c). functionalism approach; (d) the culture of materialism approach; and (e) idealism culture approach.

By adapting the characteristics of organizational culture identified by Robbins (2008:46), the school with the spiritual culture of the organization has the following characteristics (1) Focusing on the goal. Despite the important financial benefits, but a spiritual organization does not make financial profit as a primary value, (2) Focus on Individual Development. Schools that have a culture of spiritual organizations recognize the value of people in the school environment. (3) Trust and Openness. The characteristics of the school with spiritual organizational culture is mutual trust, honesty, and openness. (4) Empowerment. Climate of high confidence in the school environment with spiritual organizational culture when combined with the mission to advance learning and growing competence of teachers, school management resulted in empowering teachers and other school staff. (5) The tolerance on the expression of the school community. The last character that distinguish the spiritual organizational culture based school is that they do not cripple the emotions of the school. 


\section{Job Satisfaction of Teacher Development}

Job satisfaction is a person's general attitude towards work which shows the difference between the number of awards received by workers and the amount they believe they should receive. (Stephen $\mathrm{P}$ Robbins. \& Timothy A. Judge; 2009:723). Greenberg and Baron (2003:56) describe job satisfaction as a positive or negative attitude by the individual to their work. Matching the definition proposed by Gibson (1985:213), who expressed satisfaction at work as the attitude of the workers about their job.

Job satisfaction is an affective or emotional responses to the various aspects of a person's job. This definition indicates that job satisfaction is not a single concept. A person can be relatively satisfied with one aspect of the job and not be satisfied with one or more other aspects. (Kreitner, Robert and Angelo Kinicki; 2001:24; Wibowo, 2012:502) Two theories of job satisfaction is the most famous Two Factor Theory and Value theory. Two factors Theory explain the two factors that influence job satisfaction, namely (1) hygiene linked to the conditions surrounding the work, and (2) motivators associated with the work itself. While satisfaction Value Theory explains that occur at the level where the work of the individual received as expected. Implications of Value Theory are aspects of the work that needs to be changed to get the satisfaction. (Wibowo; 2012:503). There are five factors that can influence the emergence of job satisfaction, namely (1) need fulfillment that is where the satisfaction is determined by the level of job characteristics that give the individual an opportunity to meet their needs, (2) discrepancies is where satisfaction is determined by expectations, if the expectation is greater than the received, people will not be satisfied, (3) the value Attainment is where satisfaction is the result of the fulfillment of the value of individual work, (4) equity is where satis faction is a function of how fairly people are treated in the workplace, and (5) the genetic component is where job satisfaction is partly a function of personal characteristics and genetic factors (Kreitner, Robert and Angelo Kinicki; 2001:225). Growth satisfaction is job satisfaction of teachers who have a high value for duty of his profession. Thus, to be able to assess job satisfaction of teachers in carrying out the task of the profession can be seen by measuring job satisfaction development acquired in school. In detail, this satisfaction will be measured by indicators (1) their job satisfaction gained from the award provided by schools to the achievements of teachers in the task of his profession, (2) the recognition of principals and others in the school environment on teacher performance, (3) the magnitude of the responsibilities given to the school to teachers, (4) the opportunities and the chance provided by the school teachers to go forward, (5) their attitudes job satisfaction itself that encouraged him to continue to grow, and (4) their chances of career development given the school to the teacher.

\section{Teacher Achievement Motivation}

Motivation is the power, the urge, the need, passion, pressure, or psychological mechanism that encourages a person or group of people to achieve specific achievements in line with what he wanted. Motivation will move people to do things in accordance with the encouragement he received what he wished to have been achieved. The achievement of an obsession or an expectation of achievement will provide new motivation for individuals to perform the next achievement. So motivation can move up to the crowning achievement of all his needs is reached. (George R. Terry, 1986:25; Stephen P. Robbins, 2008:715, Sudarwan Danim; 2004:102).Robbins, Marsh, Cacioppe, and Miller (2008:312) provide restrictions on motivation as follows: "The set of processes that arouse, direct and maintain human behavior toward attaining a goal. We define motivation in regard to organizational behavior as the willingness to exert high levels of effort toward organizational goals in other so satisfy some individual need. Achievement motivation is the desire of the individual to achieve excellence in accordance with the standards that have been set. While Chalpin explains that achievement motivation is (1) a person's desire for success, (2) a desire to be involved in the task, and (3) the desire to succeed in carrying out the difficult task. While individuals who have high achievement motivation can be seen through the characteristics (1) happy to work hard to achieve success, (2) like the situation to assess their own progress and success, happy to perform the control personal top performance of its duties, (3) tends to act or set a realistic option, (4) have a time perspective of the far future. (Slavin, R.E., 1994:113; Keller,J.M., E.F. Kelly, \& Dodge; 1978:21).

From the description above can be concluded that the achievement motivation of teachers is the desire of teachers to achieve with high standard in tasks profession that meets the characteristics (1) had a desire to do something better, (2) trying to get the responsibility for solving the problem, (3) trying to get feedback on their performance quickly so that they can make improvements, (4) have a challenging goal, (5) did not like the success obtained by chance or because the factor of luck, (6) is more like a challenging job skills, and ( 7) obtain a sense of achievement and satisfaction from the work done. 


\section{Teacher Performance}

Dessler (1997:75), Rivai. (2004:14) state the notion of performance nearly equal to job performance is a comparison between the results of actual work with labor standards set. In this case the performance is more focused on the work. This shows that the "Performance is the result of work that can be achieved by a person or group of people in an organization, in accordance with the authority and responsibilities of each, in an effort to achieve the goals of the organization concerned legally, does not violate the law and in accordance with moral or ethics". Gibson (1996:28), Stolovich and Keeps (1992:53), Robbins, Stephen P. (2003:235) state that there are three performance perspective, namely (1) the performance of the individual, in the form of employee contributions in accordance status and role in the organization (2) teamwork, in the form of contributions made by the employees as a whole; and (3) the performance of the organization is the real contribution of the performance of the individual and the team as a whole. While Dessler (1997: 235), and Sutrisno, Edi. (2010:149) states that a person's performance can be measured by its ability to: (1) Skills planning: a) assess and set priorities from the field results, b) realistic designing long and short term plans, c) anticipate the problems that might be and constraints barriers towards achieving the required results; (2). Organizational skills: a). classifying activities for the optimal use of the sources of personnel in order to achieve objectives, b). clearly define responsibilities and limits of authority for subordinates, c) minimize confusion and inefficiency in work operations; (3) Skills directs: a) the ability to guide and supervise b) emphasizes the process of motivation, communication, and leadership; (4) Skill controls: a) Setting a proper procedure for informed on the progress of the work of subordinates, b) identify deviations in the progress of work purposes, c) adapt the job to be able to ensure that the goals set have been achieved.

\section{Research Methodology}

The method used in this research is quantitative research. To analyze one variable to another variable used path analysis. Path analysis require any form of linear regression significant relationship among variables. Path analysis is used to analyze the patterns of relationships between variables in order to determine the direct effect or indirect effect (exogenous variables) against a set of causal variables (endogenous variables). Furthermore, path analysis model is divided into three types: (1) correlated path models; (2) mediated path models; (3) independent path models. This type of model in this study are mediated path models. This study analyzed the effect of one variable to another variables, namely: (1) the competence of teachers, (2) the pedagogical leadership of principals; (3) spiritual organization culture of the school, (4); job satisfaction of teacher development, (5) teacher achievement motivation and (6) the performance of teachers.

The population was all teachers who teach in Senior High School in Deli Serdang district, North Sumatra Province comprise of 1089 teachers. The sample of this study using the technique of random sampling proportional Area. To calculate the number of samples used proportional random sampling technique proportional Area proposed by David De Moorgan, based on this technique obtained a sample of 284 teachers. Data collection are used a set of questionnaires that had been tested for validity and reliability. Analysis model of this research can be seen from the figure I below.

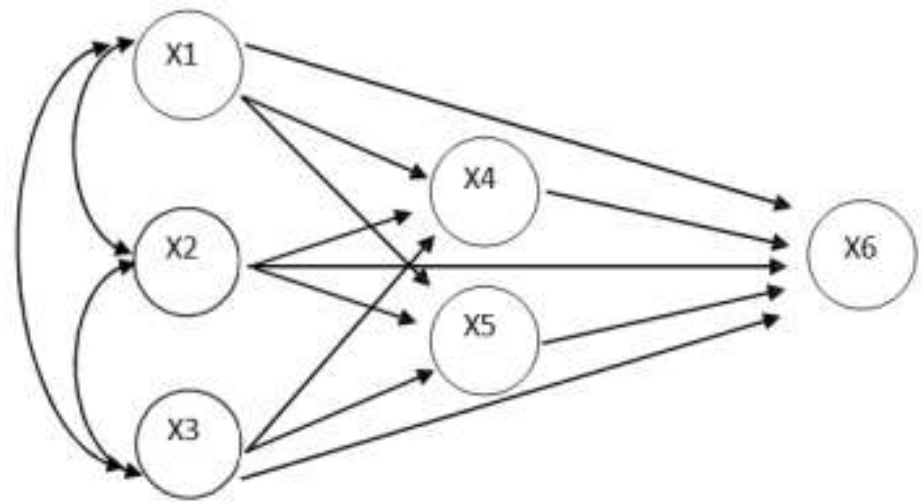

Figure 1: Research theoretical model

$\mathrm{X}_{1}=$ Teacher Competence

$\mathrm{X}_{2}=$ Principal Pedagogical Leadership

$\mathrm{X}_{3}$ = Organizational Culture of School Spiritual

$\mathrm{X}_{4}=$ Job Satisfaction of Teacher Development

$\mathrm{X}_{5}=$ Teacher Achievement Motivation

$\mathrm{X}_{6}=$ Teacher Performance 


\section{A. Description of research data}

\section{Results And Discussion}

Data collected from each variable tabulated in accordance with the purposes of analysis. Furthermore, the tabulated data have been analyzed with descriptive statistics of which calculates the value of central tendency and size distribution. Respectively in the following sections will describe the respective data variables. Description of data includes mean, median, mode; standard deviation, variance, minimum score, and maximum score. The data can be seen in this table below.

Table 1. Statistics Descriptive of All Variables

\begin{tabular}{|l|l|l|l|l|l|l|}
\hline Statistics & $\mathbf{X}_{\mathbf{1}}$ & $\mathbf{X}_{\mathbf{2}}$ & $\mathbf{X}_{\mathbf{3}}$ & $\mathbf{X}_{\mathbf{4}}$ & $\mathbf{X}_{\mathbf{5}}$ & $\mathbf{X}_{\mathbf{6}}$ \\
\hline $\mathbf{N}$ & 284 & 284 & 284 & 284 & 284 & 284 \\
\hline Mean & 138.99 & 110.23 & 136.99 & 101.66 & 107.67 & 150.99 \\
\hline Median & 141.00 & 112.00 & 140.00 & 103.00 & 109.50 & 154.00 \\
\hline Mode & 146.00 & 125.00 & 134.00 & 111.00 & 114.00 & 156.00 \\
\hline $\begin{array}{l}\text { Std. } \\
\text { Deviation }\end{array}$ & 16.42 & 15.82 & 16.46712 & 10.80 & 13.26 & 16.47 \\
\hline Variance & 269.75 & 250.37 & 271.17 & 116.54 & 175.73 & 271.19 \\
\hline Minimum & 80.00 & 64.00 & 81.00 & 67.00 & 73.00 & 107.00 \\
\hline Maximum & 172.00 & 143.00 & 168.00 & 123.00 & 134.00 & 185.00 \\
\hline
\end{tabular}

Descriptive analysis shows that teacher performance (X6) as many as 54 teachers or 19\% are classified as low, 185 teachers or $65.1 \%$ are in moderate position, and 45 teachers $15.8 \%$ are in high position. Teacher ability $\left(\mathrm{X}_{1}\right)$ based on the data reveal that 42 teachers or $14.8 \%$ are still low, $69.0 \%$ are in moderate and $16.2 \%$ are high. Principal Pedagogical Leadership $\left(\mathrm{X}_{2}\right)$ from the data reveal that as many as 61 teachers or $21.5 \%$ are in low position, 178 teachers or $62.7 \%$ are in moderate position, and 45 teachers or $15.8 \%$ are in high position. Organizational Culture of School Spiritual $\left(\mathrm{X}_{3}\right)$ based on the data reveal that 43 teachers or $15.1 \%$ were still in low position, 194 teachers or $68,3 \%$ were in moderate position and 47 teachers or $16.5 \%$ were in high position. Job satisfaction of teacher development based $\left(\mathrm{X}_{4}\right)$ on the data can be classified into three categorize, 49 teachers or $17.3 \%$ were in the low position, 185 teachers or $65.1 \%$ were in the middle position, and 50 teachers or $17.6 \%$ were in high position. Achievement Motivation (X5), based on the data as many as 52 teachers or $18.3 \%$ were in low position, 187 teachers or $65.8 \%$ were in moderate position, and 45 teachers or $15.8 \%$ were in high position. All these variable had been checked for normality, linierity, homogeneity and independency of variables as a requirement to further analysis.

\section{B. Model Analysis}

Based on the path analysis, the results of the coefficient correlation and t-values to indicate whether the model is significant or not significant can be seen on the table below.

Table 2. Summary results of the analysis of correlation coefficients and significance.

\begin{tabular}{|c|c|c|c|c|c|c|c|}
\hline \multirow{2}{*}{\multicolumn{2}{|c|}{ Matric }} & \multicolumn{6}{|c|}{ Correlation Coefficient } \\
\hline & & $\mathrm{X}_{1}$ & $\mathrm{X}_{2}$ & $\mathrm{X}_{3}$ & $\mathrm{X}_{4}$ & $\mathrm{X}_{5}$ & $\mathrm{X}_{6}$ \\
\hline \multirow{5}{*}{ Correlati on Coefficie nt } & $\mathrm{X}_{1}$ & 1 & 0.1034 & 0.1000 & 0.4418 & 0.4455 & 0.4405 \\
\hline & $\mathrm{X}_{2}$ & 0.1034 & 1 & 0.1154 & 0.4790 & 0.4852 & 0.6199 \\
\hline & $\mathrm{X}_{3}$ & 0.1000 & 0.1154 & 1 & 0.3017 & 0.4331 & 0.4169 \\
\hline & $\mathrm{X}_{4}$ & 0.4418 & 0.4790 & 0.3017 & 1 & 0.6590 & 0.7126 \\
\hline & $\mathrm{X}_{5}$ & 0.4455 & 0.4852 & 0.4331 & 0.6590 & 1 & 0.7333 \\
\hline & $\mathrm{X}_{6}$ & 0.4405 & 0.6199 & 0.4169 & 0.7126 & 0.7333 & 1 \\
\hline \multirow{2}{*}{\multicolumn{2}{|c|}{ Matrix }} & \multicolumn{6}{|c|}{ Significance coefficient $\mathrm{t}$ ( $\mathrm{t}_{\text {observation }}$ ) } \\
\hline & & $t_{1}$ & t2 & t3 & $t_{4}$ & t5 & $\mathrm{t} 6$ \\
\hline \multirow{6}{*}{$\begin{array}{l}\text { Coeffici ent } \\
\mathbf{t}_{\text {observation }}\end{array}$} & t1 & 1 & 1.7450 & 1.6880 & 8.2693 & 8.3564 & 8.2397 \\
\hline & $t_{2}$ & 1.7450 & 1 & 1.9506 & 9.1625 & 9.3190 & $\begin{array}{l}13.265 \\
3\end{array}$ \\
\hline & t3 & 1.6880 & 1.9506 & 1 & 5.3138 & 8.0701 & 7.7027 \\
\hline & t4 & 8.2693 & 9.1625 & 5.3138 & 1 & 14.714 & $\begin{array}{l}17.055 \\
8 \\
\end{array}$ \\
\hline & t5 & 8.3564 & 9.3190 & 8.0701 & $\begin{array}{l}14.713 \\
8 \\
\end{array}$ & 1 & $\begin{array}{l}18.113 \\
7\end{array}$ \\
\hline & t6 & 8.2397 & 13.265 & 7.7027 & 17.055 & 18.113 & 1 \\
\hline $\mathrm{t}$ table $(0,05)$ & 1,96 & \multirow{2}{*}{\multicolumn{6}{|c|}{ Sate Significance if: $t_{\text {observation }}>t_{\text {table }}$}} \\
\hline $\mathrm{t}$ table $(0,01)$ & 2,59 & & & & & & \\
\hline
\end{tabular}


Based on the above table, all exogenous variables have significant correlation with endogenous variables in the significance level of alpha 0.05.Based on the statistical analysis of the results obtained coefficient values: competence of teachers, pedagogical leadership of principals, school spiritual organizational culture, job satisfaction teacher development and motivation of teachers on teacher performance has a score of $0.161 ; 0.336 ; 0.175 ; 0.264$ and 0.249 with coefficient $t$ respectively $4.092 ; 8.267 ; 4.759 ; 6.318$ and 5.529 . For the coefficient $t$ table at a significance level of $95 \%$ and $99 \%$ respectively by 1,969 and 2,594. By comparing the value of the coefficient tobservation with $t$ table, it can be said that the effect given by the variables Teacher Competence, Principal Pedagogical Leadership, School Spiritual Organizational Culture, Job Satisfaction of Teacher Development, and Achievement Motivation toward the teacher's performance is stated very significant.

Next determine the coefficient of determination $\left(\mathrm{R}_{6}{ }^{2}\right)$ and the influence of other variables or variable residual (error / residue) that variability unexplained and is associated with the variable trust. The results of the analysis of each of these coefficient values of $\mathrm{R}^{2} 6 \cdot 12345=0.6988$, for coefficient values Fobservation 144.780 and $\mathrm{F}$ table $(0.05)=2.2464$ and $\mathrm{F}$ table $(0.01)=3.0836$. Based on the coefficient values produced, it can be said that the coefficient of determination diversity teacher performance is determined by the competence of teachers, pedagogical leadership of principals, school spiritual organizational culture, job satisfaction of teacher development and achievement motivation is stated very significant. The effect of other variables or residual variable (error / residue) that diversity is not explained and linked to teacher performance variable e $=0.2775$. Structural equation model that is formed: $\mathrm{f}_{\left(\mathrm{X}_{6}\right)}=0.161 \mathrm{X}_{1}+0.336 \mathrm{X}_{2}+0.175 \mathrm{X}_{3}+0.264 \mathrm{X}_{4}+0.249 \mathrm{X}_{5}$.

Based on the further analysis, the whole effect of exogenous variables to endogenous variables can be seen from the structural model below:

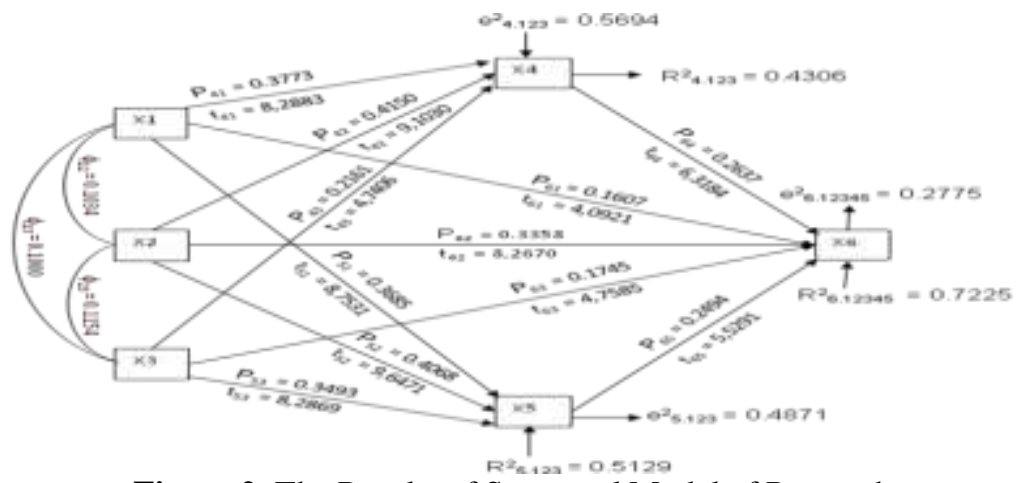

Figure 2. The Results of Structural Model of Research

Based on the Figure 2, it can be calculated the direct effect, indirect effect and total effect among exogenous variables to endogenous variables as shown in Table 2.

Table 2. Summary Results of Direct effect Analysis, Indirect Effect, Total Effect, Determination and Residues

\begin{tabular}{|c|c|c|c|c|c|c|c|c|c|c|c|c|}
\hline \multirow{4}{*}{ 兽 } & \multirow{2}{*}{\multicolumn{2}{|c|}{$\mathbf{x}_{4}$}} & \multirow{2}{*}{\multicolumn{2}{|c|}{$\mathbf{X}_{6}$}} & \multicolumn{8}{|c|}{$\mathbf{X}_{6}$} \\
\hline & & & & & \multicolumn{6}{|c|}{ Indirect Effect } & \multirow{2}{*}{\multicolumn{2}{|c|}{ Total }} \\
\hline & \multicolumn{2}{|c|}{$\begin{array}{l}\text { Direct } \\
\text { Effect }\end{array}$} & \multicolumn{2}{|c|}{$\begin{array}{l}\text { Direct } \\
\text { Effect }\end{array}$} & \multicolumn{2}{|c|}{ Direct } & \multicolumn{2}{|c|}{ Through $\mathrm{X}_{4}$} & \multicolumn{2}{|c|}{ Through $\mathrm{X}_{5}$} & & \\
\hline & $P$ & $\begin{array}{c}\mathrm{t} \\
\text { obrearve }\end{array}$ & $P$ & $\begin{array}{c}\mathrm{t} \\
\text { observet }\end{array}$ & $\mathrm{p}$ & $\mathrm{t}^{\text {oberve }}$ & $\mathrm{p}$ & $t^{\text {observe }}$ & $\mathrm{p}$ & $t^{\text {observe }}$ & $\mathrm{p}$ & $t^{\text {observe }}$ \\
\hline $\mathrm{X}_{1}$ & 0.377 & 8.288 & 0.368 & 8.753 & 0.161 & 4.092 & 0.0995 & 4.829 & 0.0919 & 4.7805 & 0.360 & 9.900 \\
\hline $\mathrm{X}_{2}$ & 0.415 & 9.103 & 0.406 & 9.647 & 0.336 & 8.267 & 0.1095 & 5.0917 & 0.1015 & 5.0718 & 0.550 & 15.35 \\
\hline $\mathrm{X}_{3}$ & 0.216 & 4.741 & 0.349 & 8.287 & 0.175 & 4.759 & 0.0460 & 3.6789 & 0.0871 & 4.6250 & 0.320 & 2.598 \\
\hline \multicolumn{5}{|c|}{$\mathrm{X} 4$} & 0.264 & 6.318 & \multirow{2}{*}{$e^{2}$} & \multirow{2}{*}{$\mathbf{R}^{2}$} & \multirow{2}{*}{ F } & \multirow{2}{*}{$\%$} & \multicolumn{2}{|c|}{ Table F } \\
\hline \multicolumn{5}{|c|}{$\mathrm{X} 5$} & 0.549 & 5.529 & & & & & 0.05 & 0,01 \\
\hline \multicolumn{7}{|c|}{$f(X 3)=0.377 X_{1}+0.415 X_{2}+0.216 X_{3}$} & 0.569 & 0.430 & 70.594 & $43 \%$ & \multirow{3}{*}{2.636} & \multirow{3}{*}{3.852} \\
\hline$f(X 4$ & $368 X$ & $\kappa_{1}+0$. & $406 \mathrm{X}$ & $\mathrm{C}_{2}+0.3$ & $49 \mathrm{X}_{3}$ & & 0.487 & 0.513 & 98.278 & $\begin{array}{c}51.3 \\
\%\end{array}$ & & \\
\hline \multicolumn{7}{|c|}{$\begin{array}{l}f(X 6)=0.161 X_{1}+0.336 X_{2}+0.175 X_{3}+ \\
0.264 X_{4}+0.549 X_{5}\end{array}$} & 0.277 & 0.723 & 14.478 & $\begin{array}{c}72.3 \\
\%\end{array}$ & & \\
\hline
\end{tabular}


Based on the Table 2 above, it can be concluded that all exogenous variables give direct effect and indirect effect significantly to endogenous variables. It is proved that Teachers' Competence, Principal Pedagogical Leadership, School Spiritual Organizational Culture, Job Satisfaction of Teacher Development, and Achievement Motivation effect significantly either directly or indirectly toward Teacher Performance of Public Senior High School in Deli Serdang District. These finding can be explained as follow:

1. Job satisfaction of teachers' development is effected directly by the teacher's competence. The better the competency of teachers in the form of knowledge, skills, and attitudes of the better growth and development of teachers, appreciation for the achievements of teachers, the opportunity to realize the independence, and the opportunity to improvise and self-development, all of which have been accommodated in the development of teachers' job satisfaction.

2. Achievement motivation of teachers is affected directly by the merits of the competency of teachers. The better the competency of teachers in the form of knowledge, skills, and attitudes of the better achievement motivation that teachers have the form: The desire to do something better, Trying to get feedback on the performance, Has a challenging goal, not like the success that chance, like a challenging job skills, and have the satisfaction for the achievements and efforts done by the teacher.

3. Teachers' Competence are very significant direct and indirect effect on teacher performance. The better the competency of teachers in the form of knowledge, skills, and attitudes of the better performance of teachers have the form: Demonstrated ability in planning quality learning, Demonstrated ability in conducting teaching and learning quality, the ability to implement educational assessment using the proper technique and use it for various purposes, teacher professionalism quality of appropriate behavior, curriculum implementation, implementation of self-development, and the Achievement of teachers and learners.

4. Principals Pedagogical leadership highly significant direct and indirect effect on the job satisfaction of teachers' development. The better the pedagogical leadership shown principals include: authority, modeling, reinforcement, pedagogical affection, firmness and sincerity, the better the growth and development of teachers, respect for the achievements of teachers, the opportunity to realize the independence, and the opportunity to improvise and self-development. All this is accommodated in the development of teacher job satisfaction variables.

5. Pedagogical leadership of principals directly affect significantly the achievement motivation. The better principal pedagogical leadership shown include: authority, modeling, reinforcement, affection pedagogical, firmness and sincerity shown and given the principal, the better the achievement motivation that teachers have in form: The desire to do something better, trying to get feed turning on performance, have a challenging goal, which incidentally does not like success, like a challenging job skills, and have the satisfaction for the achievements and efforts of the teachers.

6. Pedagogical leadership of principals is significant direct and indirect impact on teacher performance. The better leadership pedagogical shown principals include: authority, modeling, reinforcement, affection pedagogical, firmness and sincerity shown and given the principal, the better the performance of teachers have the form: Demonstrated ability in planning quality learning, Demonstrated ability in implementing quality teaching and learning activities, the ability to implement educational assessment using the proper technique and use it for various purposes, the behavior appropriate quality teacher professionalism, adherence to the curriculum, the implementation of self-development, and achievements of teachers and learners.

7. Spiritual organizational culture of the school is very significant direct and indirect impact on job satisfaction of teacher development. The better the organizational culture spiritual schools including: pay attention worthy aim, usefulness, noble values and humanity, Focus on individual development, trust and openness, empowerment, and tolerance on the expression of the school community, the better the growth and development of teachers, respect for achievements of teachers, the opportunity to realize the independence, and the opportunity to improvise and self-development, all of which have been accommodated in the development of teachers' job satisfaction.

8. Spiritual organizational culture of the school is very significant direct effect on achievement motivation of teachers. Culture spiritual organization of the school include: paying attention to the valuable usefulness, noble values and humanity, Focus on individual development, trust and openness, empowerment, and tolerance on the expression of the school community, the better the achievement motivation that teachers have the form: The desire to do something better, trying to get feedback on the performance, had a challenging goal, which incidentally does not like success, like a challenging job skills, and have the satisfaction for the achievements and efforts of the teachers.

9. Spiritual organizational culture of the school is very significant direct and indirect impact on teacher performance. The better the organizational culture spiritual schools including: Regardful worthy aim usefulness, noble values and humanity, Focus on individual development, trust and openness, 
The Determinant Factors That Effect Teacher Performance of Public Senior High School in Deli ..

empowerment, and tolerance on the expression of the school community, the better the performance of teachers have the form: show ability in planning quality learning, demonstrate the ability to carry out activities of teaching and learning quality, the ability to implement educational assessment using the proper technique and use it for various purposes, the quality of appropriate behavior professionalism of teacher training, enforceability of the curriculum, the implementation of self-development, and achievements of teachers and learners. Job satisfaction teacher development is very significant direct impact on teacher performance. The better the job satisfaction teacher development which include: the growth and development of teachers, appreciation for the achievements of teachers, the opportunity to realize the independence, and the opportunity to improvise and self-development, all of which have been accommodated in job satisfaction variables of teacher development, the better the performance of teachers have the form: demonstrated ability in planning quality learning, demonstrate the ability to carry out activities of teaching and learning quality, the ability to implement educational assessment using the proper technique and use it for various purposes, the quality of appropriate behavior professionalism of teacher training, enforceability of the curriculum, the implementation of self-development, and achievements teachers and learners. Achievement motivation of teachers are very significant direct impact on teacher performance. The better the achievement motivation that teachers have the form: The desire to do something better, trying to get feedback on the performance, had a challenging goal, not like the success of which, incidentally, like a challenging job skills, and have the satisfaction for the achievements and efforts made the teachers, the better the performance held by teachers include: demonstrated ability in planning quality learning, demonstrate the ability to carry out activities of teaching and learning quality, the ability to implement educational assessment using the proper technique and use it for various purposes, the quality of appropriate behavior professionalism of teacher, adherence to the curriculum, the implementation of self-development, and achievements of teachers and learners.

\section{Conclusion}

Based on previous findings it can be concluded that all exogenous variables significantly direct or indirect effect toward endogenous variables. The better the competency of teachers, Principals pedagogical leadership and organizational culture spiritual of school, job satisfaction of teacher development, and achievement motivation, the better the performance of teachers will be. Based on these findings, it is suggested to every people who is in charge to pay attention to these variables.

\section{References}

[1]. Ahmad, S. (2001) Kebijakan dan Keputusan Pendidikan. Jakarta: P2LPTK

[2]. Ali, Muhammad. (1987). Guru dalam Proses Belajar Mengajar. Bandung: Sinar Baru Algesindo.

[3]. Colquitt. (2009). Organizational Behavior. New York : Mc Graw - Hill.

[4]. Danim, Sudarwan. (2008). Visi Baru Manajemen Sekolah Dari Unit Birokrasi ke Lembaga Akademik. Jakarta : PT. Bumi Aksara.

[5]. Data Balitbang Depdiknas. (http://www.artikelartikel.com/2010/07/06). Diuanggah tanggal 26 April 2013.

[6]. Dessler, Gary.(1997). Human Resources Management. New Jcversey : Prantice Hall.

[7]. George R. Terry.(1986). Asas-Asas Management. Terjemahan Winardi. Bandung: Alumni.

[8]. Hersey, P., \& Blanchard, K. (1993). Manajemen Perilaku Organisasi Pendayagunaan Sumber Daya Manusia. Diterjemahkan Agus Dharma. Edisi Keempat. Jakarta : Erlangga.

[9]. James L. Gibson (1985). Organization and Management. New York : Mc Graw-Hill.

[10]. Jerald Greenberg dan A. Baron Robert. (2003). Behavior in Organizations. New Jersey: Prantice- Hall.

[11]. Kartono, Kartini. (2008). Pemimpin dan Kepemimpinan : Apakah Kepemimpinan Abnormal itu ?. Jakarta : Rajawali Press.

[12]. Katz, Daniel \& Robert L. Kahn. (1978). The Social Psychology of Organizations. New York : John Wiley \& Sons.

[13]. Keller,J.M., E.F. Kelly, \& Dodge (1978) Practitioner Guide To Concept and Measure Of Motivation Syracuse. New York: ERIC.Clearing House on Information Resources, Suracuse University.

[14]. Kreitner, Robert dan Angelo Kinicki. (2001). Organizational Behavior. New York : McGraw-Hill Companies Inc.

[15]. Kunandar.(2007). Guru Profesional. Jakarta : Raja Grafindo Persada.

[16]. Lucia, Anntoinette D dan Richard Lepsinger. (1999). The Art and Science of Competency Models : Pinprinting Critical Succes Factors in Organization. Pfeiffer : Jossey-Bass

[17]. Mangkunegara. A.A. Prabu. (2013). Evaluasi Kinerja Sumber Daya Manusia. Bandung : Rafika Aditama.

[18]. McClelland, David C. (1976). The Achieving Sociaty. New York : A Division of Macmillan Publishing Co. Inc.

[19]. McShane, Steven L and Mary Ann Von Glinow (2007). Organizational Behavior. New York: McGraw- Hill McShane, Steven L., dan Glinow, Mary Ann Von. (2007). Organizational Behavior. New York: McGraw-Hill.

[20]. Mulyasa, Edi. (2005). Menjadi Kepala Sekolah Profesional. Cetakan Kelima Bandung: Rosdakarya.

[21]. Rivai. (2004). Kepemimpinan dan Perilaku Organisasi. Jakarta : PT Raja Grafindo Persada.

[22]. Robbins, Stephen P. (2008). Organizational Behavior, Tent Edition. New Jersey : Prentice-Hall.

[23]. Slavin, R.E. (1994). Educational Psychology: Theory and Practice, (4th ed.). Boston : Allyn and Bacon

[24]. Slocum, John. W \& Hellriegel, Don. (2009). Principles of Organizational Behavior. Canada : South Western Cengage Learning.

[25]. Stephen P. Robbins. (2008). Organization Behavior Tenth Edition. New Jersey: Pearson Education Inc.

[26]. Stephen P Robbins. \& Timothy A. Judge (2009). Organizational Behavior. New Jersey: Pearson Education, Inc.

[27]. Stolovich dan Keeps, (1992). Performance. New York : Harper and Row.

[28]. Surya, M.(2005). Dampak Gaji Guru Terhadap Mutu Pendidikan. Jakarta : Suara Pembaharuan. 
[29]. Sudarwan Danim. (2004).Motivasi Kepemimpinan dan Efektivitas Kelompok. Bandung: PT. Rieneke Cipta.

[30]. Sudjana, N. (2009). Penilaian Hasil Proses Belajar Mengajar. Bandung: Rosdakarya.

[31]. Sutrisno, Edi. (2010). Manajemen Sumber Daya Manusia. Jakarta : Kencana Prenada Media Group.

[32]. Sutrisno, Edi. (2010). Budaya Organisasi. Jakarta : Kencana.

[33]. Tracey, W. R. (1974). Managing Training and Development System. USA: AMACOM.

[34]. Unimed.(2011). Laporan Hasil Pelaksanaan PLPG Tahun 2011. Medan : PSG Rayon Unimed.

[35]. Usman, Moh. Uzer. (2003). Menjadi Guru Profesional. Bandung: PT. Remaja Rosdakarya.

[36]. Wibowo. 2012. Manajemen Kinerja Edisi Ketiga. Jakarta : PT. RajaGrafindo Persada..

[37]. Yukl, Gary A . (2001). Leadership in Organization. London Prentice-Hall International. 